Original Research Paper

\title{
Implementasi Penilaian Pendidikan Karakter Kurikulum 2013 di SDK St Antonius Cakranegara
}

\author{
Harry Soeprianto $^{1^{*}}$, Nyoman Sridana ${ }^{1}$, Wahidaturrahmi \\ ${ }^{1}$ Program Studi Pendidikan Matematika FKIP, Universitas Mataram
}

*Corresponding Author:

Soeprianto, Program Studi

Pendidikan Matematika FKIP Universitas Mataram, Indonesia;

Email:

harrysoeprianto@unram.ac.id

\begin{abstract}
Abstrak: Salah satu kesulitan guru dalam mengimplementasikan kurikulum 2013 adalah penilaian. Guru menyatakan mereka belum merancang, melaksanakan, mengelolah, melaporkan, dan memanfaatkan hasil penilaian dengan baik. Kesulitan utama yang dihadapi guru adalah merumuskan indikator, menyusun butir butir instrumen, dan melaksanakan penilaian sikap dengan menggunakan berbagai macam tehnik. Selain itu banyak guru yang kurang percaya diri dalam melaksanakan penilaian pendidikan karakter, karena belum sepenuhnya memahami bagaimana menyusun instrumen dan rubrik penilaian pendidikan karakter, kesulitan yang banyak dikeluhkan guru berkaitan dengan penilaian deskripsi capaian aspek sikap, selain itu guru maupun satuan pendidikan mengalami kesulitan dalam melakukan pengolahan nilai, pemanfaatan dan pelaporannya. Memperhatikan permasalahan ini perlu mengimplementasikan panduan penilaian pendidikan karakter kurikulum 2013 di SDK ST Antonius Cakranegara agar dapat memudahkan guru dalam merencanakan, melaksanakan, dan melaporkan serta memanfaatkan hasil penilaian aspek sikap.
\end{abstract}

Kata Kunci : Penilaian, Pendidikan Karakter

\section{Pendahuluan}

Kurikulum 2013 dilaksanakan mulai tahun 2013 dalam rangka implementasi kuriklum 2013 disusun perangkat kurikulum yang meliputi kurikulum 2013 Sekolah Dasar/Madrasah Ibtidaiyah. Pedoman ini khusus mengenai Penilaian Hasil Belajar oleh pendidik pada Pendidikan Dasar dan Pendidikan Menenengah. Penilaian dalam proses pendidikan merupakan komponen yang tidak dapat dipisahkan dari komponen lainnya khususnya pembelajaran. Penilaian merupakan proses pengumpulan dan pengolahan informasi untuk mengukur pencapaian hasil belajar siswa. Penilaian hasil belajar oleh pendidik dilakukan untuk memantau proses, kemajuan belajar, dan perbaikan hasil belajar siswa secara berkesinambungan. Penegasan tersebut termaktub dalam PP Nomer 32 Tahun 2013 tentang perubahan atas PP Nomer 19 Tahun 2005 tentang standar Nasional Pendidikan. Penilaian hasil belajar oleh pendidik mempunyai peran antara lain untuk membantu peserta didik mengetahui capaian pembelajaran (learning outcomes). Berdasarkan penilaian hasil belajar oleh pendidik. Pendidik dan pesrta didik dapat memperoleh informasi tentang kelemahan dan kekuatan pembelajaran dan belajar.

Dengan mengetahui kelemahan dan kekuatannya, pendidik dan peserta didik memiliki arah yang jelas mengenai apa yang harus diperbaiki dan dapat melakukan reflektif mengenai apa yang harus dilakukannya dalam pembelajaran dan belajar. Selain itu bagi peserta didik memungkinkan melakukan proses transfer cara belajar tadi untuk mengatasi kelemahan (transfer of learning). Sedangkan bagi guru, hasil penilaian hasil belajar oleh pendidik merupakan alat untuk mewujudkan akuntabilitas profesionalnya, dan dapat digunakan sebagai dasar dan arah pengembangan pembelajaran remedial atau program pengayaan bagi peserta didik yang membutuhkan, serta memperbaiki rencana 
pelaksanaan pembelajaran (RPP) dan proses pembelajaran pada pertemuan berikutnya.

Pelaksanaan penilaian hasil belajar oleh pendidik merupakan wujud pelaksanaan tugas professional pendidik sebagaimana termaktub dalam UU Nomer 14 tahun 2005 tentang guru dan dosen. Penilaiatn hasil belajar oleh pendidik terlepas dari proses pembelajaran. Oleh karena itu, penilaian hasil belajar oleh pendidik menunjukkan kemampuan guru sebagai pendidik professional.

Dengan konteks pendidik berdasarkan standar (standard based education) kurikulum berdasarkan kompetensi (Competency based curriculum), dan ppendekatan belajar tuntas (mastery learning) penilaian proses dan hasil belajar merupakan parameter tingkat pencapaian kompetensi minimal. Untuk itu, berbagai pendekatan, strategi, metode, tehnik, dan model pembelajaran perlu dikembangkan untuk memfasilitasi peserta didik agar mudah dalam belajar dan mencapai keberhasilan belajar secara optimal.

Kurikulum 2013 mempersyaratkan penggunaan penilaian autentik (authentic assessment). Secara paradigmatic penilaian authentic memerlukan perwujudan pembelajaran autentik (authentic instruction) dan belajar authentic (authentic instruction). Hal ini diyakini bahwa penilaian autentik lebih mampu memberikan informasi kemampuan peserta didik secara holistic dan valid.

Menurut Puskur (2010), pendidikan karakter adalah segala sesuatu yang dilakukan guru, yang mampu mempengaruhi karakter peserta didik. Guru membantu membentuk watak peserta didik. Hal ini meliputi keteladanan bagaimana perilaku guru, cara guru berbicara atau menyampaikan materi, bagaimana guru bertoleransi, dan berbagai hal terkait lainnya. Berdasarkan grand design yang dikembangkan Kemendiknas tersebut, secara psikologis dan sosial kultural pembentukan karakter dalam diri individu merupakan fungsi dari seluruh potensi individu manusia (kognitif, afektif, konaktif, dan psikomotorik) dalam konteks interaksi sosial kultural (dalam keluarga, sekolah, dan masyarakat) dan berlangsung sepanjang hayat.

Pusat Pengkajian Pedagogik (P3) Universitas Pendidikan Indonesia mendefinisikan pendidikan karakter dalam setting sekolah sebagai pembelajaran yang mengarahkan pada penguatan dan pengembangan perilaku anak secara utuh yang didasarkan pada suatu nilai tertentu yang dirujuk oleh sekolah. Definisi ini mengandung makna: (1) pendidikan karakter merupakan pendidikan yang terintegrasi dengan pembelajaran yang yang terjadi pada semua mata pelajaran; (2) diarahkan pada penguatan dan pengembangan perilaku anak secara utuh; (3) penguatan dan pengembangan perilaku didasari oleh nilai yang dirujuk (Kesuma, 2011).

Pendidikan karakter merupakan upaya untuk membantu perkembangan jiwa anak-anak baik lahir maupun batin, dari sifat kodratinya kearah peradaban yang manusiawi dan lebih baik. Pendidikan karakter merupakan proses berkelanjutan dan tidak pernah berakhir (never ending process), sehingga menghasilkan perbaikan kualitas yang berkesinambungan (continous quality improvement) yang ditunjukkan pada terwujudnya sosok manusia masa depan dan berakar pada nilainilai budaya bangsa.

Pendidikan karakter tidak hanya mengajarkan mana yang benar dan mana yang salah kepada anak, tetapi lebih dari itu pendidikan karakter menanamkan kebiasaan (habituation) tentang yang baik sehingga peserta didik paham, mampu merasakan, dan mau melakukan yang baik. Dengan demikian, pendidikan karakter membawa misi yang sama dengan pendidikan akhlak atau pendidikan moral.

Pendidikan karakter sangat penting untuk diterapkan di setiap sekolah. Hal ini berkaitan erat dengan keberhasilan anak didik dalam belajar di sekolah. Saptono (2011), mengungkapkan bahwa ada empat alasan mendasar mengapa sekolah perlu lebih bersungguh-sungguh menjadikan dirinya tempat terbaik bagi pendidikan karakter yaitu: 1) karena banyak keluarga yang tidak melaksanakan pendidikan karakter; 2) sekolah tidak hanya bertujuan untuk membentuk anak yang cerdas, tetapi juga anak yang baik; 3) kecerdasan seorang anak hanya bermakna manakala dilandasi dengan kebaikan; 4) karena membentuk anak didik agar berkarakter tangguh bukan sekedar tugas tambahan bagi guru, melainkan tanggung jawab yang melekat pada perannya sebagai seorang guru.

Tujuan pendidikan karakter antara lain mengembangkan potensi kalbu/nurani/afektif peserta didik sebagai manusia dan warganegara yang memiliki nilai-nilai budaya dan karakter bangsa; mengembangkan lingkungan kehidupan sekolah sebagai lingkungan belajar yang aman, jujur, penuh kreativitas dan persahabatan (Puskur, 2010: 7) 
Pendidikan karakter bertujuan untuk meningkatkan mutu penyelenggaraan dan hasil pendidikan di sekolah yang mengarah pada pencapaian pembentukan karakter atau akhlak mulia peserta didik secara utuh, terpadu, dan seimbang, sesuai standar kompetensi lulusan. Melalui pendidikan karakter diharapkan peserta didik mampu secara mandiri meningkatkan dan menggunakan pengetahuannya, mengkaji dan menginternalisasi serta mempersonalisasi nilai-nilai karakter dan akhlak mulia sehingga terwujud dalam perilaku sehari-hari.

Sjarkawi (2011) berpendapat bahwa pendidikan karakter bagi anak bertujuan agar secara sedini mungkin dapat:

a. Mengetahui berbagai karakter baik manusia.

b. Mengartikan dan menjelaskan berbagai karakter.

c. Menunjukkan contoh perilaku berkarakter dikehidupan sehari-hari.

d. Memahami sisi baik menjalankan perilaku berkarakter.

e. Memahami dampak buruk karena tidak menjalankan karakter baik.

f. Melaksanakan perilaku berkarakter dalam kehidupan sehari-hari.

Lebih lanjut Sjarkawi (2011), menjelaskan tujuan pendidikan karakter adalah mendorong lahirnya anak-anak yang baik. Begitu tumbuh dalam karakter yang baik mereka akan tumbuh dengan kapasitas dan komitmennya untuk melakukan berbagai hal yang terbaik dan melakukan segalanya dengan benar dan cenderung memiliki tujuan hidup. Untuk itu karakter yang berkualitas perlu dibentuk dan dibina sedini mungkin, sebab jika gagal dalam menanamkan karakter anak maka akan membentuk pribadi yang bermasalah si masa dewasanya kelak.

Fitri (2012) mengemukakan bahwa pendidikan karakter bertujuan membentuk dan membangun pola pikir, sikap, dan perilaku peserta didik agar menjadi pribadi yang positif, berakhlak, berjiwa luhur dan bertanggung jawab. Selain itu, Kesuma, dkk dalam Somantri (2013) menjelaskan bahwa pendidikan karakter dalam seting sekolah memiliki tujuan sebagai berikut:

a. Menguatkan dan mengembangkan nilai-nilai kehidupan yang dianggap penting perlu sehingga menjadi kepribadian peserta didik sebagaimana nilai-nilai yang dikembangkan. b. Mengoreksi perilaku peserta didik yang tidak bersesuai dengan nilai-nilai yang dikembangkan sekolah.

c. Membangun koneksi yang harmonis dengan keluarga dan masyarakat dalam memerankan tanggungjawab pendidikan karakter secara bersama.

Indonesia Heritage Foundation (IHF) telah menyusun serangkaian nilai yang selayaknya diajarkan kepada anak-anak, yang kemudian dirangkum menjadi 9 pilar karakter yaitu:

a. Cinta Tuhan dan alam semesta beserta isinya

b. Tanggung jawab, kedisiplinan dan kemandirian

c. Kejujuran

d. Hormat dan santun

e. Kasih sayang, kepedulian dan kerjasama

f. Percaya diri, kreatif, kerja keras dan pantang menyerah

g. Keadilan dan kepemimpinan

h. Baik dan rendah hati

i. Toleransi, kedamaian dan kesatuan (Megawangi, 2010).

Pusat Kurikulum Badan Penelitian dan Pengembangan Kementrian Pendidikan Nasional (2011) telah mengidentifikasi 18 nilai pembentuk karakter yang merupakan hasil kajian empirik Pusat Kurikulum yang bersumber dari agama, Pancasila, budaya dan tujuan pendidikan nasional. 18 Nilainilai tersebut dapat di lihat pada bagan sebagai berikut

Tujuan Kegiatan pengabdian pada masyarakat ini adalah untuk meningkatkan pengetahuan dan pemahaman guru SDK St Antonius Cakranegara dalam membuat instrumen Penilaian pendidikan karakter kurikulum 2013 serta dapat mendeskrisikan

\section{Metode Pelaksanaan}

Untuk memecahkan masalah dalam pengabdian masyarakat ini, tim merancang beberapa kegiatan berikut:

1. Menjelaskan pengertian, fungsi, dan tahapan penyusunan Instrumen Penilaian Pendidikan Karakter kurikulum 2013, dengan harapan dapat dihadiri oleh semua guru guru di SDK St Antonius Cakranegara.

2. Menjelaskan peran standar proses dalam Penilaian Pendidikan Karakter kurikulum 2013 serta dapat mendeskripsikannya pada guru guru di SDK St Antonius Cakranegara. 
3. Melaksanakan pendampingan pada kegiatan Pembuatan Instrumen Penilaian Pendidikan Karakter Kurikulum 2013 serta mendeskripsikan khususnya untuk matapelajaran matematika dengan harapan dapat dihadiri oleh semua guru di SDK St Antonius Cakranegara.

\section{Khalayak Sasaran}

Sesuai dengan judul pengabdian pada masyarakat ini maka yang menjadi khalayak sasaran dalam kegiatan ini adalah guru-guru SDK "St Antonius" Cakranegara.

Kegiatan ini ada keterkaitan dengan perluasan dan pengembangan perangkat pembelajaran di Program Studi Pendidikan Matematika Jurusan PMIPA FKIP Universitas Mataram.

Metode yang akan digunakan dalam kegiatan pengabdian masyarakat ini adalah Ceramah, Tanya Jawab, Diskusi, dan presentasi. Metode ceramah digunakan pada saat menyajikan pengertian, langah langkah pembuatan dan rancangan Instrumen Penilaian Pendidikan Karakter Kurikulum 2013. metode tanya jawab, dimaksudkan untuk memberikan kesempatan pada peserta bertanya jawab tentang mendeskripsikan hasil Penilaian Pendidikan Karakter Kurikulum 2013 bila ada yang belum difahami sedang metode presentasi digunakan untuk melihat apakah peserta sudah dapat mengimplementasikan Penilaian Pendidikan KarakterKurikulum 2013 yang dibuat.

\section{Hasil dan Pembahasan}

Kegiatan pengabdian pada masyarakat telah dilaksanakan berupa Implementasi Penilaian Pendidikan Karakter Kurikulum 2013 di SDK St Antonius Cakranegara sebagai upaya peningkatan profesionalisme guru dengan menggunakan berbagai metode yang telah dikemukakan di atas.

Implementasi dilaksanakan 2 kali tatap muka. Pertemuan pertama penjelasan tentang Pedoman Penilaian Hasil belajar Pendidik, Kemudian Pendidikan Abad XXI dilanjutkan dengan Pendidikan Karakter Dalam Pembelajaran Di Sekolah. Kegiatan selanjutnya yang merupakan tatap muka kedua memberi kesempatan pada peserta untuk secara berkelompok untuk memilih kata kata operasional yang nantinya dapat digunakan untuk penilaian.
Peserta terlihat antusias dalam mengikuti kegiatan ini terlihat dari banyaknya pertanyaan dari peserta berkaitan dengan menerapakan kata-kata operasional dalam pembuatan instrumen yang akan digunakan untuk penilaian pendidikan karakter seperti jujur, disiplin, tanggung jawab dsb.

Kegiatan pengabdian pada masyarakat ini juga telah dijalin kesepakatan antara peserta pengabdian pada masyarakat dengan tim pengabdian pada masyarakat secara berkelompok untuk melanjutkan menyusun instrumen penilaian pendidikan karakter di SDK St Antonius Cakranegara dan tim pengabdian pada masyarakat memfasilitasi pendampingan secara langsung maupun online dengan harapan guru-guru di SDK St Antonius dapat menyusun instrumen dan melaksanakan penilaian pendidikan karakter dari instrumen yang telah disusun. Instrumen ini tidak sekedar untuk keperluan administrasi tetapi lebihpada peningkatan profesionalisme guru untuk meningkatkan kompetensinya yang akan berdampak pada kualitas kompetensi karakter peserta didiknya.

\section{Kesimpulan}

Kegiatan Pengabdian Pada Masyarakat ini sangat bermanfaat bagi guru-guru di SDK "St Antonius" Cakranegara. Karena dengan adanya kegiatan pengabdian pada masyarakat ini guru dapat menambah pengetahuannya tentang penerapan penilaian pendidikan karakter yang dapat meningkatkan karakter peserta didiknya sesuai dengan budaya yang dilaksanakan sekolah sesuai dengan budaya masyarakat yang santun, jujur, disiplin, bertanggung jawab, mandiri dan berkarakter.

Penerapan penilaian pendidikan karakter merupakan kewajiban guru untuk dilakukan agar dalam pembelajaran berkarakter dapat berjalan secara efektif dan efisien untuk meningkatkan karakter peserta didik menjadi budaya yang jujur, mandiri, disiplin, bertanggung jawab dan berkarakter.

\section{Daftar Pustaka}

Abdul Majid dan Dian Andayani. 2011. Pendidikan Karakter Perspektif Islam. Bandung: PT Remaja Rosdakarya. 
Badan Penelitian dan Pengembangan Pusat Kurikulum. 2010. Bahan Pelatihan Penguatan Metodologi Pembelajaran Berdasarkan Nilai-nilai Budaya untuk Membentuk Daya Saing dan Karakter Bangsa. Jakarta: Kemendiknas.

Cheng, Abel. 2010. Life Lessons Your Child Can Learn from Playing Snakes and Ladders. Diakses pada tanggal 05 Oktober 2018 dari http://www.parentwonder.com/lifelessons-your-child-can-learn-fromplaying-snakes-and-ladders/

Departemen Pendidikan Nasional. 2003. UndangUndang Nomor 20 Tahun 2003 Tentang Sistem Pendidikan Nasional. Jakarta: Depdiknas.

Edward de Bono. 2000. Pemikiran Baru Era Milenium, Penerbit Elex Kompatindo.

Fitri, Agus Zaenul. 2012. Reinverting Human Character: Pendidikan Karakter Berbasis Nilai dan Etika di Sekolah. Yogyakarta: ArRuss Media.

Jumhur. 1959. Sejarah Pendidikan. Ilmu. Bandung

Kesuma, Dharma. 2011. Pendidikan Karakter Kajian Teori dan Praktik di Sekolah. Jakarta: Bumi Aksara.

Megawangi, R. 2010. Pengembangan Program Pendidikan Karakter di Sekolah: Pengalaman Sekolah Karakter. Makalah disampaikan pada Seminar Nasional Guru di Universitas Terbuka pada tanggal 24 November 2010.

Montessori, M. 2004. The Origins of an Educational Innovation. Oxford: Rowman \& Littlefield.inc

Mulyasa, E. 2011. Manajemen Pendidikan Karakter. Jakarta: Bumi Aksara.

Puskur. 2010. Pengembangan Pendidikan Budaya dan Karakter Bangsa. Jakarta: Puskur Balitbang Kemdiknas.

Puskurbuk. 2011. Pedoman Pelaksanaan Pendidikan Karakter. Jakarta: Balitbang Kementerian Pendidikan Nasional.

Prasetyo, Zuhdan. 2013. Konsep Dasar Pendidikan IPA. Universitas Negeri Yogyakarta. Tidak diterbitkan.

Saptono. 2011. Dimensi-dimensi Pendidikan Karakter: Wawasan, Strategi, dan Langkah Praktis. Salatiga: Erlangga.
Somantri, M. 2013. Makalah Pendidikan Karakter. Bandung: Tidak diterbitkan.

Suyadi. 2013. Strategi Pembelajaran Pendidikan Karakter. Bandung: PT Remaja Rosdakarya Syarkawi. 2011. Pembentukan Kepribadian Anak: Peran Moral, Intelektual, Emosional, dan Sosial Sebagai Wujud Integrasi Jati Diri. Jakarta: Bumi Aksara 